\title{
The Role of Natural Progesterone Administration on the Levels of Progesterone-induced Blocking Factor, Interleukin-10 and the Prolongation of Gestational Length in Impending Preterm Delivery
}

\author{
${ }^{1}$ Yanne Thipasary, ${ }^{2}$ Jusuf Sulaeman Effendi, ${ }^{3}$ Anita Deborah Anwar
}

\begin{abstract}
Progesterone plays an important role in maintaining pregnancy. The success of pregnancy depends on the balance of immune response between the mother and the fetus. Progesterone regulates the immunological response through progesteroneinduced blocking factor (PIBF) which is synthesized by lymphocytes. Progesterone-induced blocking factor inhibits the production of arachidonic acid, reduced NK cell activity, and modulates the cytokine balance by increasing interleukin-10 (IL-10) level that is produced by Th2. This study aims to determine the roles of natural progesterone administration on PIBF and IL-10 levels and the increase in gestational length.

This is an experimental research with pre- and post-test design. Subjects were pregnant women who met the criteria $(n=22)$. The treatment was done for 7 days. Progesteroneinduced blocking factor and IL-10 levels were measured before and after the administration of natural progesterone and the length of gestation were noted. The study was conducted at $\mathrm{Dr}$ Hasan Sadikin Hospital within July to December 2013.

Results showed that after the administration of natural progesterone, there were increases on PIBF $(p=0.039)$ and IL-10 levels $(p=0.031)$. A positive correlation was noted between PIBF and IL-10 levels ( $r=0.549$; Spearman rank correlation test). There was also positive correlation between PIBF serum level (moderate strength correlation) and the length of gestation ( $r=0.428$; Point biserial correlation test). Progesterone-induced blocking factor serum level had more influence on the prolongation of the pregnancy compared to IL-10 level (OR: $1.016,95 \% \mathrm{Cl}: 1.001$ to $1.03 ; p=0.033$ ).

Increased levels of PIBF and IL-10 after the administration of natural progesterone on the impending preterm delivery may prolong the gestation. Progesterone-induced blocking factor serum level have more dominant role in prolongation of gestation compared to IL-10.
\end{abstract}

Keywords: Natural progesterone, PIBF, IL-10, Impending preterm labor.

How to cite this article: Thipasary Y, Effendi JS, Anwar AD. The Role of Natural Progesterone Administration on the Levels

\footnotetext{
${ }^{1}$ Specialist, ${ }^{2}$ Professor, ${ }^{3}$ Lecturer

${ }^{1-3}$ Department of Obstetrics and Gynecology, Faculty of Medicine, Padjadjaran University, Bandung, West Java Indonesia

Corresponding Author: Jusuf Sulaeman Effendi, Professor Department of Obstetrics and Gynecology, Faculty of Medicine Padjadjaran University, Bandung, West Java, Indonesia Phone: 62222032170, e-mail: jusufse@yahoo.com
}

of Progesterone-induced Blocking Factor, Interleukin-10 and the Prolongation of Gestational Length in Impending Preterm Delivery. J South Asian Feder Obst Gynae 2015;7(3):118-125.

Source of support: Nil

Conflict of interest: None

Date of received: 19 July 2015

Date of acceptance: 28 August 2015

Date of publication: December 2015

\section{INTRODUCTION}

Preterm delivery is a global problem and implicated as the second most cause of neonatal deaths in the world. The complications of preterm delivery cause nearly $35 \%$ (approximately 3.1 million) of neonatal deaths per year. ${ }^{1,2}$ Based on the data from year 2010, Indonesia ranked fifth for preterm delivery $(675,700$ births) with the ratio of $15.5 \%$ per 100 live births. ${ }^{1,3}$

Impending preterm delivery is defined as signs and symptoms of delivery during 24 to 34 weeks of gestational age, which include minimal of 2 contractions within 15 minutes that results in the cervical effacement and dilatation less than $3 \mathrm{~cm}^{4}$

Inflammation is one of the mechanisms that occur during a term and preterm delivery. Liggins et al has first declared that cervical effacement happens due to the inflammation process. Other researchers have also found that inflammation occurs in the cervix, myometrium and amnion during delivery process. Proinflammatory cytokines and chemokines are also responsible during the delivery, whether in infectious or noninfectious condition. ${ }^{5-8}$

Inflammation will activate the immunologic mechanism, such as the Th1/Th2 ratio. A balanced response between Th1 and Th2 is the key in maintaining pregnancy, by controlling the Th2 domination. Delivery itself is considered as a proinflammatory condition in which Th1 will dominate the Th1/Th2 ratio. Proinflammatory cytokine production will result in prostaglandin secretion, and thus uterus contraction will occur. ${ }^{9-11}$ Th1 acts in initiation of delivery by producing interleukin (IL)-1 $\beta$ 
as the inducer of $\mathrm{NF}-\kappa \beta$. NF- $\kappa \beta$ will regulate the expression of various genes that are related to pregnancy, such as COX-2, oxytocin and IL-8. These cytokines will affect the production of PGE2, a molecule that is related to uterus contraction. ${ }^{10}$

By the end of the pregnancy, myometrium will be activated (uterine awakening). Thus contractions will occur, influenced by a series of hormonal mechanisms, immune response to inflammation signals, cytokineprostaglandin and oxytocin production. ${ }^{9,12,13}$

Progesterone receptors are found in the peripheral mononuclear membrane cell. These receptors consist of three nongenomic groups, such as $\mathrm{mPR} \alpha, \mathrm{mPR} \beta$ and $\mathrm{mPR} \gamma{ }^{14-16}$ Through these receptors, progesterone releases immunologic effects in the peripheral circulation and endometrium. The mediator for progesterone, which acts as an immunomodulator, is called progesteron induced blocking factor (PIBF). This is a protein that is produced by activated T lymphocyte CD4+ in the peripheral blood. Progesteron induced blocking factor is activated by the binding of progesterone to the receptor in the peripheral mononuclear membrane cell. Progesterone induced blocking factor will hamper the cytolytic act of NK-cells and increase the Th2 production, therefore, influencing the Th1/Th2 ratio and increasing asymmetric antibody production for good maintenance of the pregnancy. ${ }^{17-20}$ During this immunologic mechanism, Th1 will produce proinflammatory cytokines, while Th2 will produce anti-inflammatory cytokines, such as IL-4, IL-5, IL-10, IL-13 and GM-CSF. Th2 acts in humoral immunity by increasing the antibody production to fight against extracellular pathogen, thus considered as building an anti-inflammatory environment. ${ }^{20,21}$ Interleukin-10 is an anti-inflammatory cytokine, produced by the trophoblast, desidual and human chorionic tissue. The IL-10 level will be adjusted according to the gestational age. A decrease in the basal production of IL-10 will initiate an inflammation process. ${ }^{22}$ Interleukin-10 is a potent cytokine that may directly interact with the inflammatory effects of Th1. In a study done in mice, a delivery induction will cause decrease in the level of IL-10. ${ }^{23}$

Some interventions have been done in order to prevent preterm delivery. One of them is by progestin administration. Many researchers have investigated the role of progestin administration in prevention of preterm delivery. One research done by the maternal-fetal medicine units network declared that progestin administration has significantly reduced the rate of preterm delivery. Csapo has conducted studies on progesterone administration in impending preterm delivery and suggested that progestin may have a role in maintaining the quiet phase of uterus and blocking the factors that may initiate the labor process. ${ }^{13,24}$
Da Fonseca et al utilized progestin (as derivate of natural progesterone) per vaginam to prevent preterm delivery in cases with cervical length of $\leq 15 \mathrm{~mm}$. This study showed that preterm delivery decreased significantly with the administration of progestin. ${ }^{25,26}$

Dodd et al performed a meta-analysis from 11 randomized clinical trials (RCT) about the use of intramuscular progestin 17 alpha-hydroxyprogesterone caproate (17 OHP-C) and four RCTs about the intravaginal use of natural microionized progesterone. This meta-analysis demonstrates that prevention of preterm delivery using both natural and synthetic progestin may decrease preterm delivery rate and low birth weight for babies in impending preterm delivery cases. American College of Obstetricians and Gynecologist (ACOG) suggests that the use of progestin could prevent preterm delivery especially in patients with history of preterm delivery. ${ }^{27}$

Other study suggests that women with single pregnancy, no history of preterm delivery and cervical length of $\leq 2 \mathrm{~cm}$, who receive intravaginal progestin (gel) $90 \mathrm{mg}$ or $200 \mathrm{mg}$ suppositories, are related to the reduction of preterm delivery and perinatal morbidity and mortality. ${ }^{25,28-32}$

Natural progesterone administration has no side effects for the fetus growth and development, nor adding any risk for congenital anomaly. Northen et al stated that after 4 years of observation in 278 children whose mothers received long-term natural progesterone therapy during pregnancy, none had side-effects based on the physical examination, motoric and personal-social ability. 29,33,34

On their study, Hudic et al still performed tocolytic treatment to both subject groups who received and did not receive dydrogesterone. On the subject group who did not receive dydrogesterone, no increase of PIBF nor IL-10 levels were observed. Some other studies even concluded that there was no interaction between calcium channel blocker tocolytic treatments with progesterone administration. $^{35}$

The role of progesterone in preventing preterm delivery has not been clearly explored. In female humans and primates, synthetic antiprogesterone administration causes myometrium contraction stimulation due to the inhibition of 3B-hydroxysteroid dehydrogenase, which causes a decrement of progesterone concentration and results in the initiation of the delivery process. There are two mechanisms in which progesterone may prevent preterm delivery: (1) anti-inflammatory effect against the inflammatory processes that occur during preterm delivery and (2) by increasing the local progesterone concentration on placenta, thus, preventing reduction in the function of progesterone. ${ }^{36,37}$

Progestine is thought to have anti-inflammatory effect through immunologic mechanism involving PIBF. This 
anti-inflammatory effect results in preterm delivery prevention by regulating the anti-inflammatory cytokine or by increasing the local progesterone concentration on the pregnant tissue. These mechanisms will neutralize functional progesterone withdrawal which appears in preterm delivery.

\section{SUBJECTS AND METHODS}

This study was an experimental study using a preand post-test design to evaluate the effect of natural progesterone administration as additive treatment in impending preterm delivery cases. Subjects were 22 patients with impending preterm delivery risks. Diagnosis was made based on obstetric evaluation, physical examination, nonstress test using cardiotocography and ultrasound to fulfill the inclusion and exclusion criteria.

Subjects were given nifedipine as tocolytic and $200 \mathrm{mg}$ natural progesterone in form of vaginal suppositories. Serum PIBF and IL-10 level were measured prior to natural progesterone administration by collecting $5 \mathrm{ml}$ of blood sample from the median cubital vein. Blood sample was kept frozen for 30 to 45 minutes and then centrifuged at $3000 \mathrm{rpm}$ for 15 minutes in order to obtain the serum. To analyze each variables, the serum was separated into three sample cups @ $0.5 \mathrm{ml}$ (labeled with name, date and study number) and then frozen at $-20^{\circ} \mathrm{C}$.

Subjects were then administered natural progesterone for maximum of 7 days. During the administration, subjects were observed for risk of preterm delivery in less than 7 days. Progesterone induced blocking factor and IL-10 levels were re-measured at day 7 if the subject had not yet given birth or prior to day 7 if subject had preterm delivery.

After all samples had been collected, they were packed and sent to the prodia bandung laboratory for PIBF and IL-10 level measurement by ELISA, using human PIBF immunoassay kit and IL-10 kit.

Data were analyzed using statistical program SPSS 20.0. Paired t-test (for data with normal distribution) or Wilcoxon test (for data with abnormal distribution) was used to compare the mean value of PIBF and IL-10 concentration, both on pre- and postintervention between the subject group and the control group. The result was considered to be statistically significant if $p$-value $<0.05$.

Pearson correlation test (for data with normal distribution) or Spearman correlation test (for data with abnormal distribution) was used to analyze the correlation between serum PIBF and IL-10 level. Descriptive analysis was used to evaluate the pregnancy success in percentage. Multivariate regression logistic test was used to analyze the impact of PIBF and IL-10 on gestational length.

\section{RESULTS}

This study was done from July to December 2013. Twentytwo subjects were recruited. Among them, 17 subjects were between 20 and 35 years old. The most dominant gestational age was between 30 and 34 weeks, as seen in 19 subjects. Only two subjects had history of preterm delivery.

The data for preintervention serum PIBF had normal distribution with $p$-value $>0.05$. However, the postintervention data had abnormal distribution. The pre- and postintervention IL-10 data also had abnormal distribution. Therefore, the analysis was done by using the Wilcoxon test.

Based on the Wilcoxon test analysis, postintervention PIBF level increase had a p-value 0.039 and postintervention IL-10 level increase had p-value of 0.031. Thus, both increases are statistically significant.

Table 1 showed that there was a statistically significant difference between the median PIBF value after the natural progesterone administration in prolongation of gestational length group of $<7$ days (1055) compared to group of $\geq 7$ days (1340.6) with $p$-value $<0.001$.

There was no significant difference between the median IL-10 level after the natural progesterone administration in prolongation of gestational length in the group of $<7$ days (0.48) compared to group of $\geq 7$ days (0.62) with $p$-value $=0.267$. There was an increased percentage of PIBF level on prolongation gestation length in the group of $\geq 7$ days as high as $32.7 \%$, whereas in the other group ( $<7$ days) was $-4.5 \%$ ( $p$-value $=0.026)$. There was also an increased percentage of IL-10 level on the prolongation of gestation length in the group of $\geq 7$ days as high as $110.4 \%$, compared to the $<7$ days group $(70.2 \%)$ (p-value $=0.007)$.

There was a positive correlation with moderate correlation strength between the PIBF and IL-10 level

Table 1: Increase of PIBF and IL-10 level on prolongation of gestational age for $<7$ days and $\geq 7$ days after the administration of natural progesterone

\begin{tabular}{|c|c|c|c|}
\hline \multirow[b]{2}{*}{ Variable } & \multicolumn{2}{|c|}{ Increase length of gestation } & \multirow[b]{2}{*}{ p-value } \\
\hline & $\begin{array}{l}<7 \text { days } \\
(n=7)\end{array}$ & $\begin{array}{l}\geq 7 \text { days } \\
(n=15)\end{array}$ & \\
\hline PIBF (ng/ml) & - & - & $<0.001^{*}$ \\
\hline Median & 1055 & 1340.6 & \\
\hline Range & $700.1-1256.8$ & $1068.1-1415.1$ & \\
\hline $\begin{array}{l}\text { PIBF level } \\
\text { increased (\%) }\end{array}$ & $-4.5 \%$ & $32.7 \%$ & $<0.001^{*}$ \\
\hline IL-10 (pg/ml) & & & 0.267 \\
\hline Median & 0.48 & 0.62 & \\
\hline Rentang & $0.26-1.22$ & $0.36-2.3$ & \\
\hline $\begin{array}{l}\text { IL-10 level } \\
\text { increased }(\%)\end{array}$ & $70.2 \%$ & $110.4 \%$ & $0.007^{*}$ \\
\hline
\end{tabular}

Mann-Whitney or Wilcoxon test; *Statistically significant for p-value $<0.05$ 
increase postnatural progesterone administration. By using Rank Spearman statistical analysis, this study obtained the r-value $=0.549(\mathrm{p}$-value $=0.008)$. Point Biserial correlation analysis showed a positive correlation with moderate correlation strength between PIBF level increase and prolongation of gestational length ( $\mathrm{r}$-value $=$ 0.428; p-value $=0.023$ )

Graph 1 showed a positive correlation between serum PIBF level increase percentage and serum IL-10 level increase. Therefore, higher value of the serum PIBF level correlates with higher value of the serum IL-10 level.

Graph 2 showed that there was a positive correlation between the increases in serum PIBF level to prolongation of gestational length. Higher increase in the serum PIBF level correlates in longer gestational period which reflects to good maintenance of pregnancy.

Table 2 showed that the variable with the most dominant effect on the prolongation of gestational length in patients with impending preterm delivery was serum PIBF level (coefficient value 0.16). Serum PIBF level has

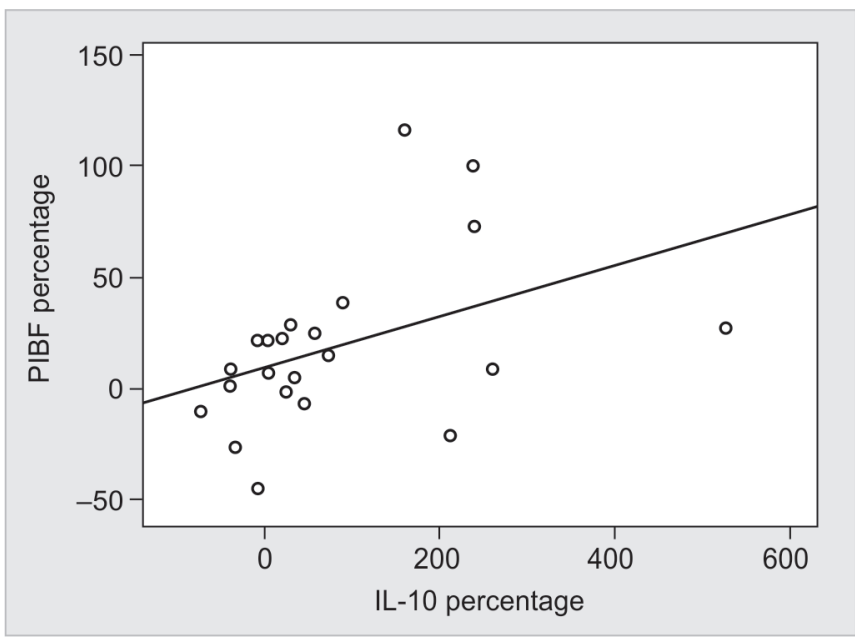

Graph 1: Correlation between PIBF level increase to IL-10 level increase

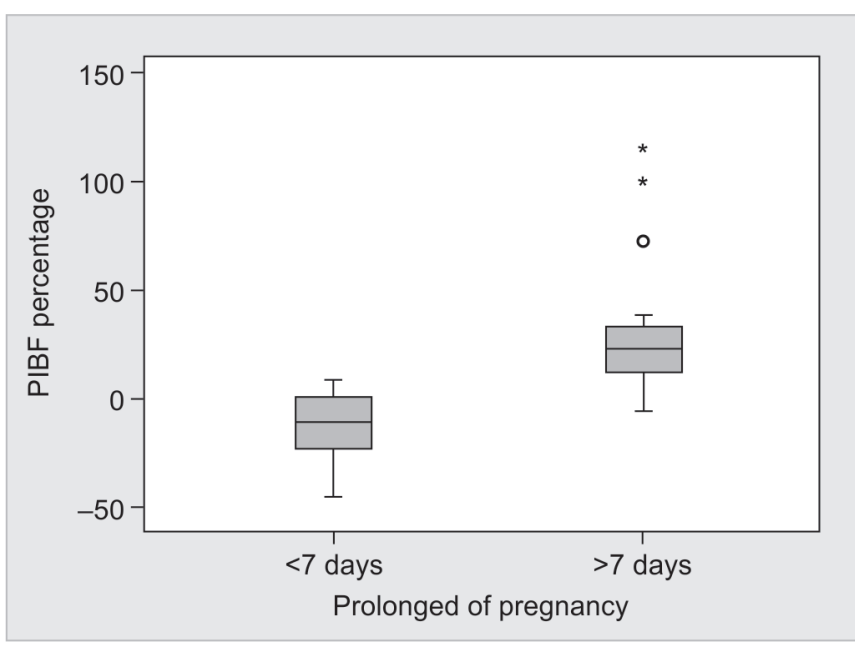

Graph 2: Correlation between serum PIBF level increase to prolongation of gestational length
Table 2: The influence of serum PIBF and IL-10 to prolongation of gestational length in patients with impending preterm delivery

\begin{tabular}{lllll}
\hline Variable & Coefficient B & SE (B) & $p$-value & OR (Cl 95\%) \\
\hline PIBF & 0.16 & 0.008 & $0.033^{*}$ & 1.016 \\
& & & & $(1.001-1.031)$ \\
IL-10 & 2.273 & 2.069 & 0.272 & $\begin{array}{l}9.713 \\
\end{array}$ \\
Constant & -19.792 & 9.342 & $0.034^{*}$ & \\
\hline
\end{tabular}

Multivariate logistic regression analysis was done with $p$-value $<0.25$; *Statistically significant, $p$-value $<0.25$

higher effect to prolongation of gestational length (OR 1.016; 95\% CI: 1.001-1.031; $\mathrm{p}=0.003)$ compared to other variables. The serum IL-10 level had no statistically significant effect on the prolongation of gestational length with OR 9.713 (95\% CI: 0.168-560.1; $\mathrm{p}=0.272$ ).

\section{DISCUSSION}

In this study, the characteristics of the subjects are described based on the maternal age, parity, gestational age, and history of prior preterm delivery. These descriptions were used because they considered as biases for the impending preterm delivery risk factors.

The main risk factor for preterm delivery is the history of prior preterm delivery. Mother with one time history of preterm delivery will have an increased risk for the next preterm delivery as much as $5 \%$. The risk will even increase to $41 \%$ in mothers with twice histories of preterm deliveries. $^{26,38}$

\section{The Influences of Natural Progesterone Administration to Serum PIBF Level in Impending Preterm Delivery}

This study showed that the serum PIBF level increased significantly (1098.5 vs 1269.6; $\mathrm{p}=0.039$ ) by the administration of natural progesterone.

This result of this study supports the result from the research done by Hudic et al which concluded that serum PIBF level in impending preterm delivery is lower than the normal pregnancy $(171.12 \pm 162.06$ vs $272.85 \pm$ 114.87; $\mathrm{p}<0.05) .{ }^{39}$ Hudic et al also stated that there was a significant increase of the mean serum PIBF level preand postdydrogesterone administration in patients with impending preterm delivery (138.92 \pm 96.64 vs $289.21 \pm$ 165.9; $\mathrm{p}<0.01)$. In this study, subjects still received tocolytic treatment, whether they received dydrogesterone or not. On the control group, there were no significant increases of serum PIBF nor IL-10 level. This suggested that tocolytic treatment did not influence PIBF and IL-10 level on dydrogesterone status administration. ${ }^{35}$ Study done by Gaspar and Hajagos-Thot stated that there was no interaction between tocolytic medication (such as calcium channel blocker) and progesterone. Study done 
by Khajehpour et al stated that progesterone administration may increase ritodrine (beta-2 adrenergic receptor agonist) efficacy. ${ }^{40}$

Vrachnis stated that the PIBF level in women with impending preterm delivery was lower than normal delivery. ${ }^{41}$ Progesterone induced blocking factor produced by the progesterone receptor on lymphocyte and CD8+ and CD4+ desidual. Raghupathy concluded that peripheral PIBF level would be lower in abortus and preterm delivery cases. Progesterone induced blocking factor would be detected in the maternal serum and is correlated with the pregnancy success. In pathologic pregnancy, PIBF level would be lower, and thus can be used as a diagnostic tool for impending preterm delivery cases. ${ }^{17,18,20}$

\section{The Effect of Natural Progesterone Administration to Serum IL-10 Level in Impending Preterm Delivery}

Interleukin-10 is an anti-inflammatory cytokine which produced by the trophoblast, desidual and human chorionic tissue. The IL-10 level will be adjusted according to the gestational age. A decrease in basal production of IL-10 will initiate an inflammation process. ${ }^{22}$ Interleukin-10 is a potent cytokine that may directly interact with the inflammatory effects of Th1. In research done in mice, a delivery induction will cause a decrease in IL-10 level. ${ }^{23}$ Clinically, serum IL-10 level in women with impending preterm delivery is lower than in women with normal pregnancy. $^{41}$

Hudic et al stated that IL-10 level in patients with impending abortus and preterm delivery is lower, whereas the levels of IFN $\gamma$ and IL-2 tend to be increased. ${ }^{39,42}$

This result differs from Tsiartas et al whose study concluded that as much as $40 \%$ (out of 142 ) subjects with impending preterm delivery had labor in $<7$ days and these patients had higher serum IL-10 level compared to the other group who had more prolonged labor. ${ }^{43}$

A study by Afriana et al stated that serum IL-10 level in impending preterm delivery group is higher than in normal pregnancy. This increase may be due to: (1) increase of IL-10 as response to raised cytokine production from Th1, (2) raised anti-inflammatory IL-10 level as a marker of delivery initiation.

Research done by Mitchell stated that IL-10 production by the amniotic tissue is part of the defense mechanism against delivery acceleration (inflammatory response). ${ }^{44}$

Larsen and Hwang also found a significant increase of IL-10 level during preterm delivery. In mice, preterm delivery is marked by the increase of proinflammatory cytokines and the decrease of IL-10 level. Same results also were noticed in research using chorionic villi culture. Raised IL-10 level is found in both preterm and term delivery. This result is contradicted with several theories. A negative feedback mechanism against the proinflammatory factors during delivery may be responsible for this phenomenon. In large scale evaluation using umbilical blood, researchers found raised IL-10 level along with increased IL-2, IL-4, IL-5 and IL-8 levels. ${ }^{7}$

Table 2 showed a significant increase of serum IL10 , pre- and postnatural progesterone administration $(\mathrm{p}$-value $=0.031)$.

\section{The Relationship between PIBF Level with IL-10 Level in Impending Preterm Delivery}

Progesterone-induced blocking factor has important roles in maintaining pregnancy through several mechanisms, such as: ${ }^{18}$

- Increasing 'the blocking antibody' asymmetrically

- Domination of Th2

- Lowering the NK cell activities

Balanced response between Th1 and Th2 is the main key in maintaining pregnancy. Th2 must dominate during pregnancy to protect fetus from being detected and eliminated by the maternal immune system on maternal-fetus interface. ${ }^{18,20}$

Table 3 showed a positive correlation with moderate strength between serum PIBF level and serum IL-10 level during natural progesterone administration ( $\mathrm{r}=0.549$; Rank Spearman test; p-value $=0.008$ ). This results was based on an in vitro study, which showed that progesterone increased the tendency of Th2 domination and decreased the Th1 production through immunomodulatory mechanism: $\mathrm{PIBF}$ - a protein produced by the activated peripheral CD8+ lymphocyte T. This protein will inhibit the cytolytic act of NK cell, increase the production of Th2 cytokines and has antiabortus effect in mice. ${ }^{17-20}$

Progesterone-induced blocking factor has an important role in inhibiting the NK cell activity. The second mechanism of PIBF is by inducing the Th2 cytokine response. Progesterone induced blocking factor facilitates the production of IL-3, IL-4 and IL-10, whereas IL-12 and IFN $\gamma$ (from Th1) will be depressed both in vitro and in vivo. ${ }^{18,20,42,45,46}$

Table 3: Correlation between PIBF and IL-10 level increase and prolongation of gestational length after natural progesterone administration for 7 days

\begin{tabular}{lll}
\hline Correlation & $\begin{array}{l}\text { Correlation } \\
\text { coefficient } r\end{array}$ & $p$-value \\
\hline Increase PIBF level with IL-10 level & $0.549^{*}$ & 0.008 \\
Increase PIBF level with increase & $0.482^{* *}$ & 0.023
\end{tabular}

of length of gestation

Note: Statistically significant if $p<0.05$; ${ }^{*}$ Rank Spearman coefficient correlation; ${ }^{* *}$ Point biserial coefficient correlation; $r<0.4$ : weak correlation; $0.4<r<0.7$ : moderate correlation; $0.7<r<0.8$ : strong correlation; $r>0.8$ : very strong correlation 
Kyurkchiev et al stated that progesterone caused apoptosis and increased the IL-10 secretion. Therefore, it is thought that progesterone may have influence in regulating the immune response. Kyurkchiev, in his study, performed dendritic cell culture which obtained from the human desidual monocyte cell. Increased progesterone level will induce PIBF and IL-10 production along with IL-12 blocking. ${ }^{47}$

\section{The Relationship between PIBF Level with Prolongation of Gestational Length in Impending Preterm Delivery}

In Table 3, it is shown that based on the point biserial correlation analysis, there is a positive correlation with moderate strength $[\mathrm{r}=0.428$ ( $\mathrm{p}$-value $=0.023)]$ between increased PIBF level with prolongation of gestational length. This result is similar to other studies which stated that a high serum progesterone level may pass the placental barrier and thus increase the Th2 domination in the maternal and fetus circulation through PIBF mediation. This phenomenon may inhibit the production of Th1 cytokines and induce the production of Th2 cytokines, thus increasing the immune-humoral response. Therefore, a high progesterone level in maternal-fetus interface plays an important role in maintaining pregnancy. ${ }^{16,20,35,39,48-50}$

Larsen and Hwang stated that progesterone had interaction bond with lymphocyte that will produce PIBF. Progesterone-induced blocking factor has immunomodulatory function that increase the Th2 signaling pathway through IL-4 activation via JAK/STAT pathway along with a decrease in phospholipase A2 which will also decrease the production of prostaglandin. The study was done in mice, however, human also produce PIBF which has important role in maintaining pregnancy. ${ }^{7}$

\section{The Influence of Serum PIBF Level and IL-10 Level to Prolongation of Gestational Length}

Progesterone acts as a potent immunomodulator in immune system by inhibiting $\mathrm{T}$ cell proliferation, increasing IL-10 production, regulating the antibody production, decreasing monocyte oxidation process and lowering the proinflammatory cytokine production. The effect of progesterone to Th1/Th2 ratio is carried by increasing the production of IL-4, IL-5 and anti-inflammatory cytokine, such as IL-10. Based on in vitro study, progesterone may increase the tendency of Th2 domination and decrease the Th1 production. During pregnancy, Th2 will dominate in the systemic circulation and in the placental barrier. Pharmacologically, progesterone will inhibit the production of Th1 cytokine and induce the cytokine production from Th2 and IL-10, thus increasing immune-humoral response. ${ }^{17-20,49}$
Vrachnis stated that IL-10 is a potent cytokine that may directly interact with the inflammatory effect of Th1. Several studies have shown that IL-10 is one of the major anti-inflammatory cytokines that suppresses the proinflammatory cytokines. Medications or external agents that affects the immune system are called as immunomodulator agents. These agents may act as immunosuppressor or immunostimulant. Several treatments, such as IL-10 administration, antioxidant therapy, antibody therapy against MIF are said to have roles in preventing preterm delivery and perinatal morbidities. ${ }^{41}$

Study done by Rivera on pregnant mices that were given Lipopolysaccharide (LPS) as proinflammatory agent showed premature deliveries, intrauterine growth retardation and fetus death. Some of the mices received IL-10 treatment and this treatment showed to improve the outcome by increasing the fetal body weight and lowering the proinflammatory cytokines (NO, TNF- $\alpha$ ) and apoptosis. ${ }^{40,51}$

Hudic et al stated that in patients with impending abortus and preterm delivery, the IL-10 level would be decreased and the IFN- $\gamma$ and IL-2 level would be increased. Hudic et al also stated that synthetic progesterone administration may increase the serum PIBF and IL-10 level. In that study, 34\% of the subjects who received progesterone had preterm delivery, which is less than those who did not receive progesterone (43.3\%) $(\mathrm{p}<0.05) .{ }^{39,42}$ The study did not mention about the role of PIBF nor the profiles of cytokines that responsible for the prolongation of gestational length.

Table 2 showed that the serum PIBF level had significant influence on prolongation of gestational length, with statistic significance (OR 1.016; 95\% CI: 1.001-1.0031; $\mathrm{p}$-value $=0.033)$. The influence of serum IL-10 level on prolongation of gestational length was not significant (OR 9.713, 95\% CI : 0.168-560.1; p-value = 0.272).

\section{CONCLUSION}

Increased level of serum PIBF and IL-10 postnatural progesterone administration in patients with impending preterm delivery will prolong the gestational length. Increased level of serum PIBF has a more dominant role compare to level of serum IL-10 in prolonging the gestational length.

\section{REFERENCES}

1. Blencowe $\mathrm{H}$, Cousens S, Oestergaard M, Chou D, Moller AB, Narwal R, et al. National, regional and worldwide estimates of preterm birth rates in the year 2010 with time trends since 1990 for selected countries: a systematic analysis and implications. The Lancet 2012 Jun;379(9832):2162-2172. 
2. Danielian P, Hall M. The epidemiology of preterm labour and delivery. In: Norman JE, Greer I, editors. Preterm Labour, Managing Risk in Clinical Practice. 1st ed: Cambridge University; 2005. p. 1-25.

3. Badan Penelitian dan Pengembangan Kesehatan Departemen Kesehatan RI. Riset Kesehatan Dasar 2007. Jakarta: Departemen Kesehatan RI; 2008.

4. Krisnadi SR, Mose JC, Effendi JS. Pedoman diagnosis dan terapi obstetri dan Ginekologi Dr. Rumah Sakit Hasan Sadikin. 1st ed. 2005.

5. Romero R, Espinoza J, Kusanovic LJP, Friel LA, Nien JK, Gonc F. Inflammation in preterm and term delivery. Sem in Fetal and Neonatal Med 2006;11(5):317-326.

6. Christiaens I, Zaragoza DB, Guilbert L, Robertson SA, Mitchell BF, Olson DM. Inflammatory processes in preterm and term parturition. J Reproduct Immunol 2008;79(1):50-57.

7. Larsen B, Hwang J. Progesterone interactions with the cervix: translational implications for term and preterm birth. Infectious Dis Obstet Gynecol 2011;2011(353297):1-13.

8. Liggins. Premature delivery of foetal lambs infused with glucocorticoids. J Endocrinol 1969;45(4):515-523.

9. Challis JR, Lockwood CJ, Myatt L, Norman JE, Strauss JF, Petraglia F. Inflammation and Pregnancy. Rep Sci 2009;16(2): 206-215.

10. Sykes L, MacIntyre DA, Yap XJ, Teoh TG, Bennett PR. The Th1: th2 dichotomy of pregnancy and preterm labour. Mediators of inflammation 2012;2012(967629):1-12.

11. Wilczynski JR. Th1/Th2 cytokines balance yin and yang of reproductive immunology. Eur J Obstet Gynecol Reproduct Biol 2005;122(2):136-143.

12. Norwitz ER, Lye SJ. Biology of parturition. In: Creasy RK, Resnik R, Iams JD, Lockwood CJ, Moore TR, editors. Maternal and Fetal Medicine. 6th ed. California: WB Saunders; 2009. p. 69-80.

13. Romero R, Lockwood CJ. Pathogenesis of spontaneous preterm labor. In: Creasy RK, Resnik R, Iams JD, Lockwood CJ, Moore TR, editor. Maternal and Fetal Medicine. 6th ed. California: WB Saunders; 2009. p. 522-532.

14. Strauss JF, Barbieri RL. Yen and Jaffe's reproductive endocrinology: physiology, pathophysiology, and clinical management. 6th ed. Philadelphia, PA: Saunders/Elsevier; 2009.

15. Dressing GE, Goldberg JE, Charles NJ, Schwertfeger KL, Lange CA. Membrane progesterone receptor expression in mammalian tissues: a review of regulation and physiological implications. Steroids [Review] 2011;76(1-2):11-17.

16. Dosiou C, Hamilton AE, Pang Y, Overgaard MT, Tulac S, Dong J, et al. Expression of membrane progesterone receptors on human T lymphocytes and Jurkat cells and activation of G-proteins by progesterone. J Endocrinol 2008;196:67-77.

17. Dosiou $\mathrm{C}$. The immune system \& reproductive processes: highlights from the postgraduate course. In: Lockwood CJ, editor. 54th Annual Scientific Meeting of the Society for Gynecologic Investigation; 2007; Philadelphia. Society for Gynecologic Investigation; 2007. p. 27-31.

18. Druckmann Re, Druckmann M-A. Progesterone and the immunology of pregnancy. J Steroid Biochemistry Molecular Biol 2005;97(5):389-396.

19. Raghupathy R, Al-Mutawa E, Al-Azemi M, Makhseedb M, Azizieh F, Szekeres-Bartho. Progesterone-induced blocking factor (PIBF) modulates cytokine production by lymphocytes from women with recurrent miscarriage or preterm delivery. J Reproduct Immunol 2009;80(1-2):91-99.
20. Szekeres-Bartho J, Barakonyi A, Par G, Polgar B, Palkovics T, Szereday L. Progesterone as an immunomodulatory molecule. Int Immun Phar 2001;1(6):1037-1048.

21. Walch KT, Huber JC. Progesterone for recurrent miscarriage: truth and deceptions. Prac Res Clin Obstet Gynaecol 2008; 22(2):375-389.

22. Mitchell MD, Simpson KL, Keelan JA. Labor-associated changes in interleukin-10 production and its regulation by immunomodulators in human choriodecidua. J Clin Endoc Metab 2007;83(12):4332-4337.

23. Gustafsson C,Hummerdala P, Matthiesen L, Berg G, Ekerfelt C, Ernerudh J. Cytokine secretion in decidual mononuclear cells from term human pregnancy with or without labour: ELISPOT detection of IFN- $\gamma$, IL-4, IL-10, TGF- and TNF- $\alpha$. J Rep Imm 2006;71(1):41-56.

24. Renzo D, Rosati A, Mattei A, Gojnic M, Gerlia S. The changing role of progesterone in preterm labour. BJOG 2005;112(1):57-60.

25. da Fonseca EB, Damiao R, Nicholaides K. Prevention of preterm birth based on short cervix: progesterone. Seminars Perinatol 2009;33(5):334-337.

26. Cunningham FG, Leveno KJ, Bloom SL, Hauth JC, Rouse DJ, Spong CY. Williams Obstetrics. 23rd ed. The McGraw-Hill Companies Inc; 2010.

27. Wisanskoonwong P, Fahy K, Hastie C. The effectiveness of medical interventions aimed at preventing preterm birth: a literature review. Women and Birth 2011;24(4):141-147.

28. da Fonseca EB, Bittar RE, Damiao R, Zugaib M. Prematurity prevention: the role of progesterone. Current Opinion Obstet Gynecol 2009;21(2):142-147.

29. Berghella V. Progesterone and preterm birth prevention: Translating Clinical Trials Data into Clinical Practice. Am J Obstet Gynecol 2012;206(5):376-386.

30. Fonseca EB, Celik E, Parra M, Singh M, Nicolaides KH, Fetal medicine foundation second trimester screening G. Progesterone and the risk of preterm birth among women with a short cervix. New England J Med 2007;357(5):462-469.

31. Joshi D, Sharma T. Role of micronised progesterone in prevention of preterm labour in high risk pregnancies. Int J Pharm Res Sci 2013;2(1):458-462.

32. Csapo AI. The 'see-saw' theory of parturition. CIBA Found 1977;47:159-210.

33. Dodd JM, Crowther CA. The role of progesterone in prevention of preterm birth. Int J Women's Health 2009;1:73-84.

34. Northen AT, Norman GS, Anderson K, Moseley L, Divito M, Cotroneo $\mathrm{M}$, et al. Follow-up of children exposed in utero to 17 alpha-hydroxyprogesterone caproate compared with placebo. Obstet Gynecol 2007;110(4):865-872.

35. Hudic I, Szekeres-Bartho J, Fatusic Z, Stray-Pedersen B, Dizdarevic-Hudic L, Latifagic A, et al. Dydrogesterone supplementation in women with threatened preterm delivery - the impact on cytokine profile, hormone profile, and progesterone-induced blocking factor. J Reproduct Immunol 2011;92(1-2):103-107.

36. Progesterone and preterm birth prevention: translating clinical trials data into clinical practice. Am J Obstet Gynecol [Practice Guideline] 2012;206(5):376-386.

37. How HY, Sibai BM. Progesterone for the prevention of preterm birth: indications, when to initiate, efficacy and safety. Theurapeutic and Clinical Risk Manag 2009;5(1):55-64.

38. Goldenberg RL, McClure EM. The epidemiology of preterm Birth. In: Berghella V, editor. Preterm Birth: prevention and management. 1st ed. Blackwell Publishing Ltd; 2010. p. 22-34. 
39. Hudić I, Fatušić Z, Szekeres-Bartho J, Balić D, Polgar B, Ljuca D, et al. Progesterone-induced blocking factor and cytokine profile in women with threatened preterm delivery. Am J Reproduct Immunol 2009;61(5):330-337.

40. Gáspár R, Hajagos-Tóth J. Calcium channel blockers as tocolytics: Principles of their actions, adverse effects and therapeutic combinations. Pharmaceuticals 2013;6(6):689-699.

41. Vrachnis N, Malamas FM, Sifakis S, Tsikouras P, Iliodromiti Z. Immune aspects and myometrial actions of progesterone and CRH in labor. Clinical and Development Immunol 2012; 2012(937618):1-10.

42. Hudic I, Fatusic Z. Progesterone-induced blocking factor (PIBF) and $\mathrm{Th}(1) / \mathrm{Th}(2)$ cytokine in women with threatened spontaneous abortion. J Perinat Med 2009;37(4):338-342.

43. Tsiartas P, Holst R, Wennerholm UB, Hagberg H, Hougaard DM, Skogstrand K, et al. Prediction of spontaneous preterm delivery in women with threatened preterm labour: a prospective cohort study of multiple proteins in maternal serum. BJOG 2012;119(7):866-873.

44. Mitchell M, Simpson K. Paradoxical proinflammatory actions of interleukin-10 in human amnion: potential roles in term and preterm labor. J Clin Endoc Metab 2004;89(8): 4149-4152.
45. Boggess KA, Bailit JL, Singer ME, Parisi VM, Mercer BM. Projected benefits of universal or scheduled antepartum corticosteroids to prevent neonatal morbidity: a decision analysis. Am J Obstet Gynecol 2005;193(4):1415-1423.

46. Polgar B, Nagy E, Miko E, Varga P, Szekeres-Bartho J. Urinary progesterone-induced blocking factor concentration is related to pregnancy outcome. Bio Reproduct 2004;71(5):1699-1705.

47. Kyurkchiev D, Ivanova-Todorova E, Altankova I. Progesterone increase apoptosis and interleukin 10 secretion by mature monocyte derived dendritic cells. Biotechnol 2007;21(4): 468-470.

48. Stjernholm YV. Progesterone in human pregnancy and parturition. In: Dubey RK, editor. Sex Hormones. 1st ed. Intech; 2012.

49. Zen M, Ghirardello A, Iaccarino L, Tonon M, Campana C, Arienti $\mathrm{S}$, et al. Hormones, immune response, and pregnancy in healthy women and SLE patients. Swiss Med Wkly 2010; 140(13-14):187-201.

50. Gonzalez DA, Diaz BB, Rodriguez Perez Mdel C, Hernandez AG, Chico BN, de Leon AC. Sex hormones and autoimmunity. Immunol Letters 2010;133(1):6-13.

51. Rivera DL, Olister SM, Liu X, Thompson JH, Zhang XJ, Pennline K, et al. Interleukin-10 attenuates experimental fetal growth restriction and demise. FASEB J 1998;12(2):189-197. 